\title{
Repeated Administration of Amphetamine or Cocaine Does Not Alter AMPA Receptor Subunit Expression in the Rat Midbrain
}

\author{
Wenxiao Lu, M.D., Lisa M. Monteggia, Ph.D., and Marina E. Wolf, Ph.D.
}

We previously reported that ventral tegmental area (VTA) dopamine neurons are supersensitive to AMPA when recorded three days after discontinuing repeated amphetamine or cocaine administration. By increasing dopamine cell activity, this may contribute to the induction of behavioral sensitization. The goal of this study was to determine if increased sensitivity to AMPA reflects increased AMPA receptor expression in the midbrain. Immunolabeling for GluR1, GluR2, GluR2/3, and GluR4 was quantified by immunohistochemistry with ${ }^{35} S$-labeled secondary antibodies in VTA, substantia nigra, and a transitional area. First, rats were treated for five days with saline or amphetamine $(5 \mathrm{mg} / \mathrm{kg})$ and killed three or 14 days after the last injection. No significant changes in immunolabeling were observed for any subunit at either withdrawal time. GluR1 immunolabeling was further examined in rats killed 16-18 hrs or 24 hrs after a single injection of amphetamine or repeated injections of saline, amphetamine $(5 \mathrm{mg} / \mathrm{kg} \times 5$ days $)$ or cocaine $(20 \mathrm{mg} / \mathrm{kg} \times 7$ days). No significant differences were observed in any region. Finally, neither repeated amphetamine or cocaine administration significantly altered GluR1 mRNA levels as quantified by reverse transcriptase-polymerase chain reaction. Our results suggest that enhanced responsiveness of VTA dopamine neurons to AMPA after withdrawal from repeated stimulant administration involves mechanisms more complex than increased expression of AMPA receptor subunits.

[Neuropsychopharmacology 26:1-13, 2002]

(C) 2001 American College of Neuropsychopharmacology. Published by Elsevier Science Inc.
KEY WORDS: Addiction; Behavioral sensitization; Glutamate receptors; Substantia nigra; Ventral tegmental area

Behavioral sensitization refers to the persistent augmentation of behavioral responses to psychomotor stimulants that occurs as a result of their repeated administration. It provides an animal model for neuroadaptations that may contribute to drug addiction (Robinson and

From the Department of Neuroscience, FUHS/The Chicago Medical School, North Chicago, IL.

Dr. Lisa Monteggia's present address: Department of Psychiatry, UT Southwestern Medical Center, 5323 Harry Hines Blvd, Dallas, TX 75390-9070.

Address correspondence to: Dr. Marina E. Wolf, Department of Neuroscience, FUHS/The Chicago Medical School, 3333 Green Bay Road, North Chicago, IL 60064-3095.

Received 27 November 2000; revised 23 March 2001; accepted 3 April 2001.

Online publication: 4/25/01 at www.acnp.org/citations/Npp 042501110 .
Berridge 1993). Sensitization is initiated by drug actions within the ventral tegmental area (VTA), the origin of mesocorticolimbic dopamine (DA) projections (Kalivas and Stewart 1991). It is now well accepted that the induction of sensitization requires glutamate transmission within the VTA (Wolf 1998; Vanderschuren and Kalivas 2000). Glutamate's involvement in sensitization implies mechanistic similarities between sensitization and other forms of neuronal plasticity. This in turn has important implications for the development of therapeutic strategies for drug dependency (Li et al. 2000).

Sensitization can be induced by treatments that have in common the ability to produce brief but intense activation of VTA DA cells (Schenk and Snow 1994; Ben-Shahar and Ettenberg 1994). Moreover, many lines of evidence suggest that DA cell activity is increased shortly after discontinuation of repeated stimulant administration (White 
1996; Wolf 1998). These findings suggest that the physiological mechanisms responsible for induction involve a transient increase in excitatory drive to VTA DA cells. Electrophysiological results suggest that this might be due, in part, to a transient increase in the responsiveness of VTA DA neurons to $\alpha$-amino-3-hydroxy-5-methylisoxazole-4-priopionate (AMPA) receptor stimulation. Thus, VTA DA neurons recorded three but not 14 days after discontinuation of repeated cocaine or amphetamine administration show increased responsiveness to the excitatory effects of iontophoretically applied glutamate and AMPA (White et al. 1995; Zhang et al. 1997).

Increased AMPA receptor expression is one possible explanation for this increase in responsiveness to AMPA. Indeed, GluR1 levels in the VTA, quantified using Western blots, are increased shortly after discontinuation of repeated cocaine, morphine, ethanol, or stress paradigms (Ortiz et al. 1995; Fitzgerald et al. 1996; Churchill et al. 1999). While increased GluR1 levels might explain enhanced responses to AMPA after repeated cocaine or amphetamine administration, an important concern is that increased GluR1 has been demonstrated after 16-24 hrs of withdrawal from psychostimulants (Fitzgerald et al. 1996; Churchill et al. 1999) whereas the increase in electrophysiological responsiveness to AMPA has been demonstrated after 3 days of withdrawal (White et al. 1995; Zhang et al. 1997). This difference in withdrawal times is not trivial. Sensitization occurs because of a time-dependent cascade of different cellular changes, and the early withdrawal period is a particularly fluid one (e.g., Ackerman and White 1990). A critical test of this hypothesis, therefore, is to determine if elevation of GluR1 levels coincides temporally with increased electrophysiological responsiveness to AMPA. Therefore, one goal of this study was to quantify AMPA receptor subunit levels in rat midbrain three and 14 days after discontinuation of the same amphetamine regimen used in electrophysiological studies. A second goal was to examine levels of GluR1 mRNA and immunolabeling at shorter withdrawal times to assess the possibility of extremely transient changes in GluR1 expression.

\section{METHODS}

\section{Animals and Drug Treatments}

Male Sprague-Dawley rats (Harlan, Indianapolis, IN), weighing 200-225 $\mathrm{g}$ at the start of experiments, were used. All procedures were in strict accordance with the National Institutes of Health Guide for the Care and Use of Laboratory Animals. Rats were housed 2/cage in a colony room maintained under constant temperature and humidity on a 12-hr light/dark cycle. Rats were handled for 3-4 days before treatment began.

Four experiments were performed $(n=8-10$ rats in all groups): 1) For studies of GluR1-4 immunolabeling in midbrain at three and 14 day withdrawal times, rats received saline $(1 \mathrm{ml} / \mathrm{kg}$, i.p.) or d-amphetamine sulfate (5 $\mathrm{mg} / \mathrm{kg}$, i.p.) on five consecutive days and were killed three days or 14 days after the last injection; 2) For studies of GluR1 immunolabeling at an earlier withdrawal time, rats were killed 16-18 hrs after one of four regimens [five days of saline injections (saline group), four days of saline followed by one day of $5 \mathrm{mg} / \mathrm{kg}$ d-amphetamine (acute amphetamine group), five days of $5 \mathrm{mg} / \mathrm{kg}$ d-amphetamine (chronic amphetamine group), or seven days of 20 $\mathrm{mg} / \mathrm{kg}$ cocaine (chronic cocaine group)]; 3) Four groups of rats received the same regimens described in part 2 but were killed $24 \mathrm{hrs}$ after the last injection; 4) Three groups of rats were used for competitive reverse transcriptasepolymerase chain reaction (RT-PCR) analysis of GluR1 mRNA levels in VTA. Rats received either six days of saline injections (saline group), five days of $5 \mathrm{mg} / \mathrm{kg}$ $\mathrm{d}$-amphetamine sulfate (chronic amphetamine group), or seven days of $20 \mathrm{mg} / \mathrm{kg}$ cocaine (chronic cocaine group), and all were killed 16-18 hrs after the last injection. The cocaine regimen used in Experiments 2-4 is identical to one of those employed by Fitzgerald et al. (1996) for Western blotting studies.

\section{Autoradiographic Immunohistochemistry}

Because of the large number of rats involved in the study, perfusions were staggered over several consecutive days. All rats were perfused between 9 AM and 1 PM. To minimize variability, small groups of rats, that included both drug treated and saline treated rats, were perfused simultaneously. Rats were anesthetized with sodium pentobarbital $(55 \mathrm{mg} / \mathrm{kg}$, i.p.) and perfused with $200 \mathrm{ml}$ of ice-cold saline, followed by $400 \mathrm{ml}$ of fixative solution containing $4 \%$ paraformaldehyde (Sigma), $1.5 \%$ sucrose and $0.1 \mathrm{M}$ phosphate buffer $(\mathrm{pH} 7.2)$. Following perfusion, the brains were removed and immersed in the above fixative solution for another hour. Then, brains were immersed sequentially in solutions containing $0.1 \mathrm{M}$ phosphate buffer, $0.1 \%$ sodium azide and either 10,20 , or $30 \%$ sucrose. Sections $(40 \mu \mathrm{M})$ were cut frozen on a sliding microtome and sequentially placed into 6 wells of a cell culture plate. At the completion of sectioning, each section group (one well) contained 6-7 sections that sampled the rostral-caudal extent of the midbrain at $240 \mu \mathrm{m}$ intervals. One section group was used for immunohistochemistry with each antibody. Sections were stored free-floating in cryoprotectant solution $[30 \%$ sucrose, $30 \%$ ethylene glycol, and $0.1 \mathrm{M}$ phosphate buffer $\mathrm{pH} 7.2$ ] at $-20^{\circ} \mathrm{C}$.

At the time of analysis, sections were transferred, using a paintbrush, from cryoprotectant solution into a plastic net (Brain Laboratories, Boston, MA) in a glass dish. Sections were rinsed in $0.1 \mathrm{M}$ phosphate buffer $\left(\mathrm{pH}\right.$ 7.2) $\left(\mathrm{PO}_{4}\right)$ for $4 \times 10 \mathrm{~min}$ and then in $0.1 \mathrm{M}$ phosphate buffer containing $0.3 \%$ Triton $\mathrm{X}-100\left(\mathrm{PO}_{4} / \mathrm{T}\right)$ for 
$4 \times 10 \mathrm{~min}$. After incubating in 10\% horse serum (Life Technologies, Grand Island, NY) in $\mathrm{PO}_{4} / \mathrm{T}$ for 30 min to block background staining, sections were transferred into wells of cell culture plates containing primary antibodies in $10 \%$ horse serum and $\mathrm{PO}_{4} / \mathrm{T}$, and incubated 1-4 days at $4^{\circ} \mathrm{C}$ with continuous agitation by a mixer (Thermolyne, Dubuque, IA).

The primary antibody concentrations were: $0.5 \mu \mathrm{g} /$ $\mathrm{ml}$ for anti-GluR1, anti-GluR2, and anti-GluR4; and 0.25 $\mu \mathrm{g} / \mathrm{ml}$ for anti-GluR2/3. After rinsing in $\mathrm{PO}_{4} / \mathrm{T}$ for $4 \times$ 10 min and in $\mathrm{PO}_{4} / \mathrm{T}$ containing $10 \%$ horse serum for 10 $\mathrm{min}$, sections were incubated with ${ }^{35} \mathrm{~S}$-labeled anti-rabbit IgG antibody (1:100-1:300 dilution) or anti-mouse IgG antibody (1:100-1:300 dilution) at room temperature for 1-2 hrs with continuous gentle agitation. Sections were rinsed in $\mathrm{PO}_{4} / \mathrm{T}(4 \times 10 \mathrm{~min})$ and in $\mathrm{PO}_{4}(4 \times$ $10 \mathrm{~min}$ ) and then mounted onto gelatin-coated microslides. Sections from saline and drug treated groups were processed simultaneously throughout all steps of the immunohistochemical procedure. All sections were mounted on the same day in random order, to avoid differential loss of signals during storage in $\mathrm{PO}_{4}$ prior to mounting. Sections were exposed to BioMax-MR films (Kodak, Rochester, NY) with ${ }^{14} \mathrm{C}$-standard microscale strips (Amersham) for 1-4 days. Films were developed with GBX developer (Kodak) for $4 \mathrm{~min}$ and fixed with rapid fixer (Kodak). Sections from saline and drug treated groups with the same withdrawal time were exposed to the same film, to avoid possible differences between films.

\section{Image Analysis}

Autoradiographs on films were scanned by a Power Macintosh G3 and an Apple-One Scanner (Macintosh, Cupertino, CA). The scanner can resolve 256 gray levels from white to black. Midbrain coronal sections were divided into three portions according to Paxinos and Watson (1986): a rostral portion (interaural 3.70-4.50 $\mathrm{mm}$; 2-3 coronal sections/section group), an intermediate portion (interaural $3.2-3.70 \mathrm{~mm}$; two sections/ section group) and a caudal portion (interaural 2.70-3.20 $\mathrm{mm}$; two sections/section group). Thus, a total of $6-7$ coronal sections between interaural 2.7-4.5 were examined for each rat, on both right and left sides. A transitional area exists between substantia nigra and VTA, where the medial substantia nigra and ventrolateral VTA are gradually merged. Thus, three areas (substantia nigra, transitional area, and VTA) were quantitatively examined at each of the three rostral-caudal levels described above, for a total of nine midbrain subregions: rostral substantia nigra, intermediate substantia nigra, caudal substantia nigra, rostral transitional area, intermediate transitional area, caudal transitional area, rostral VTA, intermediate VTA, and caudal VTA. These are depicted in Figure 1. Lack of visible boundaries on autoradiographs prevented us from distinguishing between substantia nigra pars compacta and pars reticulata, so both are included in analysis of the substantia nigra. NIH Image software was used for quantitative analysis of autoradiographs based on optical density (O.D.), which was calibrated to nano-curies (nCi) per gram of dry tissue weight based on gray levels generated by ${ }^{14} \mathrm{C}$-standard microscale strips.

Within the VTA, transitional area and substantia nigra, there are areas that should not be included in the analysis of specific signals, such as white matter areas located within these structures, blood vessels, and areas where the section was damaged. To separate such areas from those with specific signals, the threshold function of the NIH Image program was employed with a cut-off value. The cut-off value was determined by making background measurements in surrounding regions and was defined as the mean of these background measure-
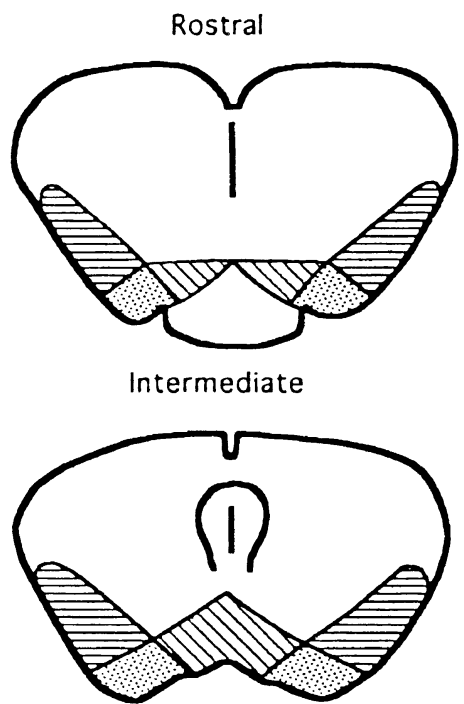

Caudal
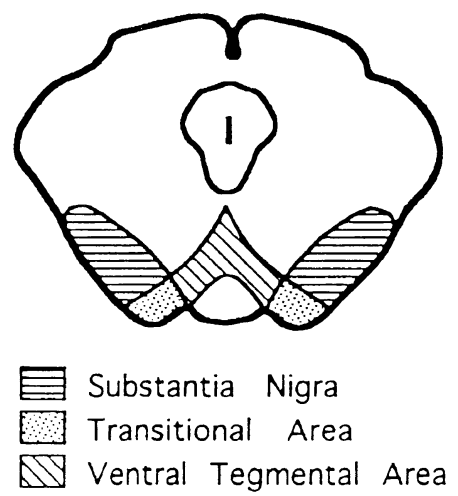

Figure 1. Midbrain coronal sections were divided into three portions: a rostral portion (interaural 3.7-4.5 $\mathrm{mm}$ ), an intermediate portion (interaural $3.2-3.7 \mathrm{~mm}$ ) and a caudal portion (interaural $2.7-3.2 \mathrm{~mm}$ ), according to Paxinos and Watson (1986). For each of these three portions, substantia nigra, VTA and a transitional area between substantia nigra and VTA were defined as shown. Thus, nine subregions of each rat midbrain were analyzed. 
ments +2 standard deviations (to set the cut-off level at a point that would be greater than $95 \%$ of all background measurements). The red nucleus was often used to make background measurements because GluR1 expression is very low in this region. Areas that exhibited values lower than this cutoff were defined as background. In areas with values greater than the cutoff, the specific signal was defined as the total signal minus the mean background signal. Data are expressed as nano-curies (nCi) per gram of dry tissue weight.

\section{Total RNA Isolation}

Rats were decapitated 16-18 hrs after the last injection. The VTA was dissected from a 2-mm thick coronal slice (approximate coordinates: interaural 2.5-4.5), made using a brain mold (Activational Systems, Detroit, MI). Tissue was homogenized in guanidinium isothiocynate solution [5 M guanidinium thiocyanate, $50 \mathrm{mM}$ HEPES (pH 7.0), 0.5\% Sarcosyl, and $100 \mathrm{mM} \beta$-mercaptoethanol] and total RNA was extracted (Chomczynski and Sacchi 1987). To minimize DNA contamination, a second sodium acetate/phenol-chloroform extraction was carried out. Total RNA concentration was determined by spectrophotometer measurements at $260 \mathrm{~nm}$.

\section{Preparation of RT-PCR Internal Control}

The internal control (i.e., the competitor) was constructed from the full-length rat GluR1 cDNA, p59/2, kindly provided by Drs. Jim Boulter and Stephen Heinemann (Salk Institute). This construct was in the pBluescript SK (-) vector (Stratagene, La Jolla, CA) in the same orientation as the T3 promoter. The plasmid p59/2 contained two Bsm I restriction sites at nucleotides 959 and 1277 relative to the ATG in the GluR1 gene. Restriction enzyme digestion with Bsm I and religation produced a GluR1 construct with a deletion of $318 \mathrm{bp}$, encoding amino acids 320-426. Competent Escherichia coli (DH5 $\alpha)$ cells were transformed with the ligation mixtures and clones were selected for ampicillin resistance $(50 \mu \mathrm{g} / \mathrm{ml})$. Positive clones were tested for the appropriate deletion by PCR as described below. This construct was designated pGluR1 $\Delta$.

To synthesize the cRNA internal standard for competitive PCR, the plasmid pGluR1 $\Delta$ was linearized by digestion with XhoI, which cuts within the polylinker of the vector, and transcribed using T3 polymerase and an Ambion Transcription Kit (Austin, TX) according to manufacturer's instructions. After treatment of the DNA template with an RNase-free DNase I and phenol/chloroform extraction, pGluR1 $\Delta$ was precipitated by addition of $0.1 \mathrm{vol}$ of $3 \mathrm{M}$ sodium acetate $(\mathrm{pH}$ 5.2) and $2.5 \mathrm{vol}$ of absolute ethanol. RNA transcripts were dried and resuspended in diethyl-pyrocarbonate treated water. The yield of pGluR1 $\Delta$ transcription product was quantified at $260 \mathrm{~nm}$ on a spectrophotometer. The RNA was used as an internal control in RT-PCR studies.

\section{Competitive RT-PCR}

Total VTA RNA was reverse-transcribed using a GluR1 gene specific primer, designated primer 3 (Figure 2). Primer 3, 5'-GTCTGGTCTGTCCCTCTTC-3', corresponds to nucleotides 1927-1907 of rat GluR1 relative to the ATG site. In amplification reactions, the sense primer (Primer 1) 5'-CAAGGAGAGCGGACGCAATG-3' and antisense primer (Primer 2) 5'-CGCTGACAATCTCAA GTCGG-3' correspond to nucleotides 926-946 and 15781558 of rat GluR1 relative to the ATG, respectively. These primers do not show homology to GluR2-4 sequences and do not distinguish between flip and flop variants of GluR1. First strand cDNA synthesis was carried out by initially annealing $1.0 \mu \mathrm{g}$ of VTA total RNA with $0.2 \mu \mathrm{M}$ primer 3 and varying amounts of pGluR1s (10 pg to $1 \mathrm{fg}$ ) at $80^{\circ} \mathrm{C}$ for $2 \mathrm{~min}$ to reduce secondary structures. The mixture was removed and cooled on ice. It was then mixed with $30 \mu \mathrm{l}$ of $2 \mathrm{X}$ PCR buffer [ $20 \mathrm{mM}$ Tris $\mathrm{HCl}, \mathrm{pH} 8.3 ; 100 \mathrm{mM} \mathrm{KCl} ; 3 \mathrm{mM} \mathrm{MgCl} 2 ; 0.002 \%$ $(\mathrm{w} / \mathrm{v})$ gelatin; $400 \mu \mathrm{M}$ each dATP, dTTP, dCTP and dGTP], $1 \mu l$ of the RNase Inhibitor InhibitAce (5'-3', West Chester, PA), $300 \mathrm{U}$ of Superscript reverse transcriptase (Gibco Life Technologies, Gaithersburg, MD) and water to make a total reaction volume of $60 \mu \mathrm{l}$. The reaction was incubated at $37^{\circ} \mathrm{C}$ for 1 hour. Then, the reverse transcriptase was inactivated for $5 \mathrm{~min}$ at $95^{\circ} \mathrm{C}$, placed on ice, aliquoted and frozen at $-80^{\circ} \mathrm{C}$. Prior to PCR assays, primer 1 was labeled with $\gamma^{3}{ }^{33}$ P-ATP (3000 $\mathrm{Ci} /$ mmole, Amersham) using T4 polynucleotide kinase (Gibco Life Technologies, Gaithersburg, MD) according to the manufacturer's instructions. The enzyme was inactivated at $65^{\circ} \mathrm{C}$, primer was separated from free nucleotides with a Sephadex G-25 spin column, and the incorporation of radioactivity was determined by liquid scintillation counting. A typical reaction yielded $1-2 \times$ $10^{6} \mathrm{cpm} / \mathrm{pmol}$ of labeled primer.

PCR was performed using $5 \mu$ l of the above cDNA, 2X PCR buffer (see above), $0.4 \mu \mathrm{M}$ each of primers 1 and 2, approximately 5-8 $\times 10^{6} \mathrm{cpm}$ of labeled primer 1, and 2.5 U AmpliTaq polymerase (Perkin-Elmer Cetus, Norwalk, CT). The samples were denatured at $80^{\circ} \mathrm{C}$ for $1 \mathrm{~min}$, and then amplified at $93.3^{\circ} \mathrm{C}$ for $24 \mathrm{sec}, 59^{\circ} \mathrm{C}$ for $22 \mathrm{sec}$, and $72^{\circ} \mathrm{C}$ for $78 \mathrm{sec}$ for 32 cycles, the linear range for both target and competitor, in a Perkin-Elmer 9600 Thermal Cycler. An aliquot of each reaction was electrophoresed through an $8 \%$ polyacrylamide gel. The gels were dried, placed in PhosphorImager cassettes to expose, and the incorporation of radioactivity into each band was determined by densitometry.

\section{Data Analysis}

For autoradiographic immunohistochemistry experiments, saline and drug treated groups from the same withdrawal time were compared using a two-tailed 


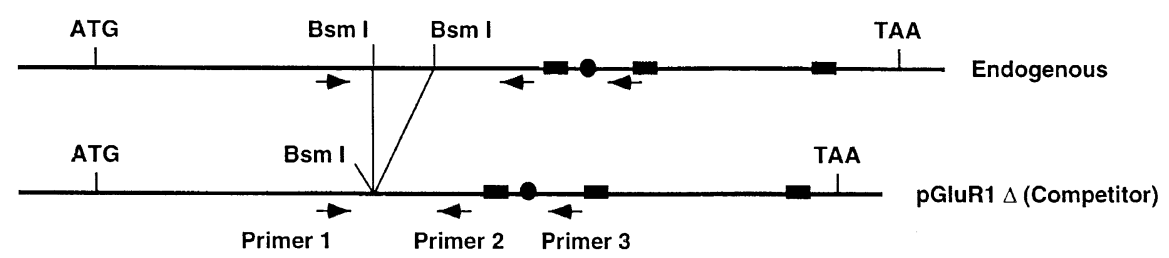

Figure 2. Construction of a GluR1 Internal Standard (pGluR1 $\Delta$ ) for competitive RT-PCR. The cDNA of rat GluR1 is shown at the top of this figure. A $318 \mathrm{bp}$ segment of GluR1 was removed using two endogenous Bsm I sites to generate pGluR1 1 . The pGluR1 1 construct was used to synthesize cRNA for use in RT-PCR as described in Materials and Methods. The proposed three transmembrane domains are indicated by rectangles (TM1, TM3, and TM4); a fourth hydrophobic section (M2) is indicated by a circle. Primers are indicated by arrows. Primer 3 was used in RT reactions. Primers 1 and 2 were used in PCR amplification.

Student's t-test with significance set at $p<.05$. For figures, data for drug treated groups are expressed as percentage of the corresponding saline control group (e.g., amphetamine/3 day withdrawal rats are compared to saline/ 3 day withdrawal rats). For competitive RT-PCR experiments, data from amphetamine, cocaine and vehicle groups were compared using ANOVA.

\section{Materials}

(+)-Amphetamine sulphate was obtained from Sigma Chemical Co. (St. Louis, MO). (-)-Cocaine hydrochloride was obtained from the Research Technology Branch of the National Institute on Drug Abuse. All GluR antibodies were obtained from Chemicon (Temecula, CA).

\section{RESULTS}

\section{Controls for Immunohistochemistry}

Although the specificity of the GluR antibodies used in this study has been confirmed previously (Wenthold et al. 1992; Vissavajjhala et al. 1996), additional control experiments were performed. First, we verified that preincubation of primary or secondary antibodies at high temperature $\left(100^{\circ} \mathrm{C}, 15 \mathrm{~min}\right)$ eliminated specific staining. Second, we showed that pre-incubation of anti-rabbit IgG secondary antibody with $10 \%$ rabbit serum (room temperature, 2 hrs) eliminated specific staining. Third, we verified that preadsorption with the synthetic peptide used to raise the anti-GluR1 antibody eliminated specific staining in midbrain sections. For the latter studies, the antigen peptide (SHSSGMPLGATGL, corresponding to amino acids 877-889 in the C terminal domain of GluR1) was synthesized by Genosys Biotechnologies Inc. (TX).

Overnight preincubation at $4^{\circ} \mathrm{C}$ of anti-GluR1 antibody $(0.5 \mu \mathrm{g} / \mathrm{ml})$ with increasing concentrations of synthetic GluR1 peptide $(0.01-10 \mu \mathrm{g} / \mathrm{ml})$ reduced specific staining in a concentration-dependent manner. Peptide concentrations equal or greater to $1 \mu \mathrm{g} / \mathrm{ml}$ reduced staining to background levels (Figure 3). Finally, we verified that specific staining was also eliminated by preadsorption with the BSA-conjugated form of the peptide (kindly provided by Dr. Robert J. Wenthold, National Institutes of Health; data not shown).

\section{GluR1-4 Immunolabeling in Midbrain Sections}

Glutamate receptor subunit expression was quantified by autoradiographic immunohistochemistry in rostral, intermediate and caudal subregions of the VTA, the substantia nigra, and a transitional area between the two (nine subregions total, shown in Figure 1). Moderate levels of GluR1 and GluR2 and lower levels of GluR2/3 and GluR4 immunolabeling were observed throughout the midbrain, with somewhat higher labeling observed in the substantia nigra than the VTA. These results are consistent with previous findings (Martin et al. 1993; Petralia and Wenthold 1992; Paquet et al. 1997; Jakowec et al. 1998; Albers et al. 1999).

\section{GluR1-4 Immunolabeling after Repeated Amphetamine or Cocaine Administration}

GluR1-4 immunolabeling was determined after the same amphetamine regimen $(5 \mathrm{mg} / \mathrm{kg} /$ day $\times 5$ days $)$ and withdrawal times (three or 14 days) used in previous electrophysiological studies of AMPA receptor responsiveness (White et al. 1995; Zhang et al. 1997). For each rat, the average level of immunoreactivity in each midbrain subregion was determined on both right and left sides of the appropriate coronal sections (2-3 sections per subregion). The mean of such determinations was then calculated for each treatment group ( $n=8-10$ rats). Each drug treated group was compared with a saline control group from the corresponding withdrawal time. Data are expressed as percentage of the corresponding saline group.

Results for GluR1 are presented in Figure 4, whereas results obtained with antibodies recognizing GluR2, GluR2/3 and GluR4 are shown in Table 1. Compared to saline treated rats, the amphetamine treated rats did not exhibit a significant change in immunolabeling for any of the AMPA receptor subunits at either the three or 14-day withdrawal time. There was, however, a trend towards increased GluR1 levels 


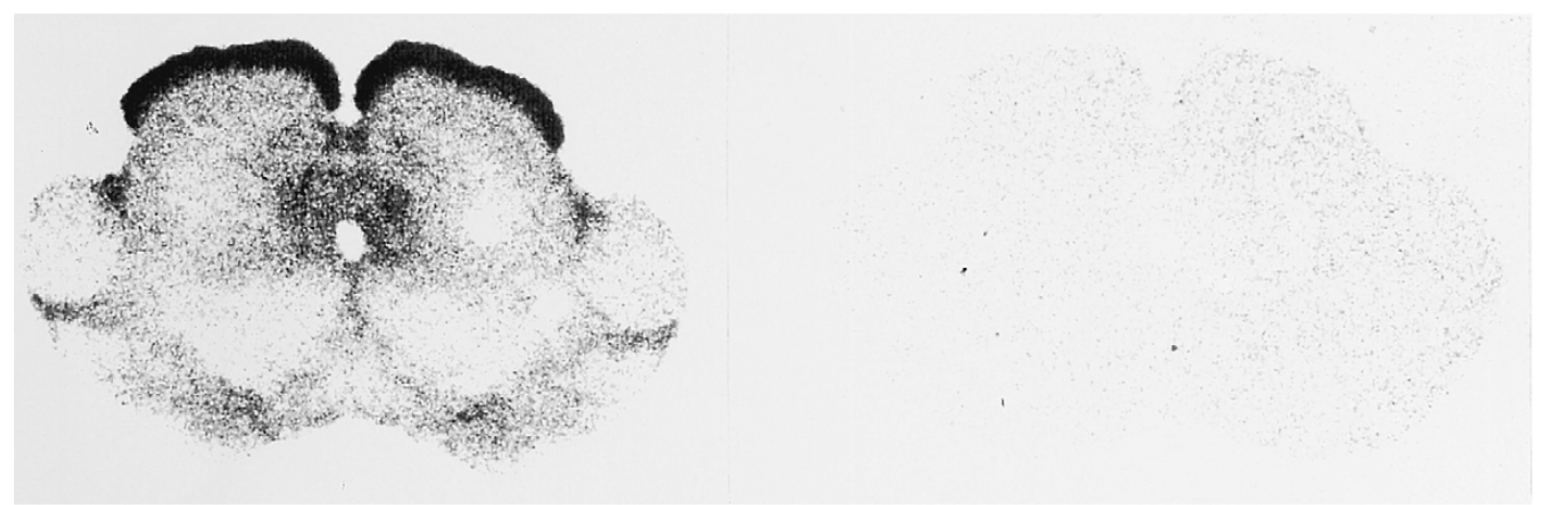

Figure 3. Specificity of the GluR1 antibody in rat midbrain sections as demonstrated by preadsorption studies with the synthetic peptide used to generate the antibody. Left: Immunolabeling with GluR1 antibody $(0.5 \mu \mathrm{g} / \mathrm{ml})$ and ${ }^{35} \mathrm{~S}-\mathrm{labeled}$ secondary antibody. Right: Immunolabeling under the same conditions except that GluR1 antibody was incubated overnight with $10 \mu \mathrm{g} / \mathrm{ml}$ of the antigen peptide. Staining is reduced to background levels.

at the three-day withdrawal time in all portions of the substantia nigra and the transitional area, and in the intermediate portion of the VTA. This regional pattern is different from that observed by Fitzgerald et al. (1996), who reported increased GluR1 levels in the VTA but not in the substantia nigra at a $16-18 \mathrm{hr}$ withdrawal time. Nevertheless, these findings raised the possibility that there may have been an early change in GluR1 levels that dissipated substantially by the three-day withdrawal time but was still functionally significant.

We therefore examined GluR1 immunolabeling in separate groups of rats treated with the same amphetamine regimen but killed 16-18 hrs after the last injection. To control for residual effects of the last amphetamine injection of the chronic regimen, a control group was included that received saline on Days 1-4 and $5 \mathrm{mg} / \mathrm{kg}$ amphetamine on Day 5 . We also included a group that received the same chronic cocaine regimen $(20 \mathrm{mg} / \mathrm{kg} /$ day $\times 7$ days $)$ used in the study by Fitzgerald et al. (1996). Figure 5 demonstrates that there were no significant changes in GluR1 immunolabeling in any of the nine subregions of rat midbrain following either a single injection or repeated injections of amphetamine. Surprisingly, we also failed to detect a significant change in GluR1 immunolabeling after repeated cocaine, even though this regimen produced an increase in GluR1 as measured by Western blotting (Fitzgerald et al. 1996). Although some subregions showed a small trend towards increased GluR1 levels, this occurred in the acute amphetamine group as well as the chronically treated groups, and was not confined to the VTA (see Discussion).

A final experiment examined GluR1 immunolabeling in rats that received the same saline, amphetamine, or cocaine regimens but were killed at a slightly longer withdrawal time ( $24 \mathrm{hrs})$. Again, no significant changes in GluR1 immunolabeling were observed in any drugtreated group compared to saline controls (Figure 6). Many of the small, non-significant trends that were observed in the 16-18-hrs withdrawal experiment were not evident in this experiment.

\section{GluR1 mRNA Levels after Repeated Amphetamine Administration}

To quantify GluR1 mRNA levels, we constructed a GluR1 internal standard to be used for competitive RTPCR (Figure 2; see Materials and Methods for a detailed description). The PCR primers were designed to span the 318 base pairs (bp) deleted region of the internal standard. This primer pair amplifies both the competitor and the target gene in the same reaction tube. Thus, amplification performed with these primers generated bands of 652 and $334 \mathrm{bp}$ for endogenous GluR1 and the GluR1 internal standard, respectively (Figure 7). Although the competitor shares the same primer-binding site as the target cDNA, we wanted to verify that the efficiency of amplification was similar for both. Approximately equal molar quantities of GluR1 cDNA and the competitor, pGluR1s, were added to a single PCR reaction along with radiolabeled primer. Aliquots of the PCR reaction were removed at various cycle numbers between 15 and 40 . The PCR products were electrophoresed on a polyacrylamide gel, the gels were dried, and the incorporation of radioactivity was determined by densitometry. The linear portions of the two curves exhibited nearly identical slopes, indicating that the amplification efficiencies of the target DNA and competitor DNA were very similar (data not shown).

We performed competitive RT-PCR using VTA total RNA obtained from rats treated repeatedly with saline, amphetamine or cocaine and killed 16-18 hrs after last injection. Drug regimens were identical to those de- 


\section{GluR 1}

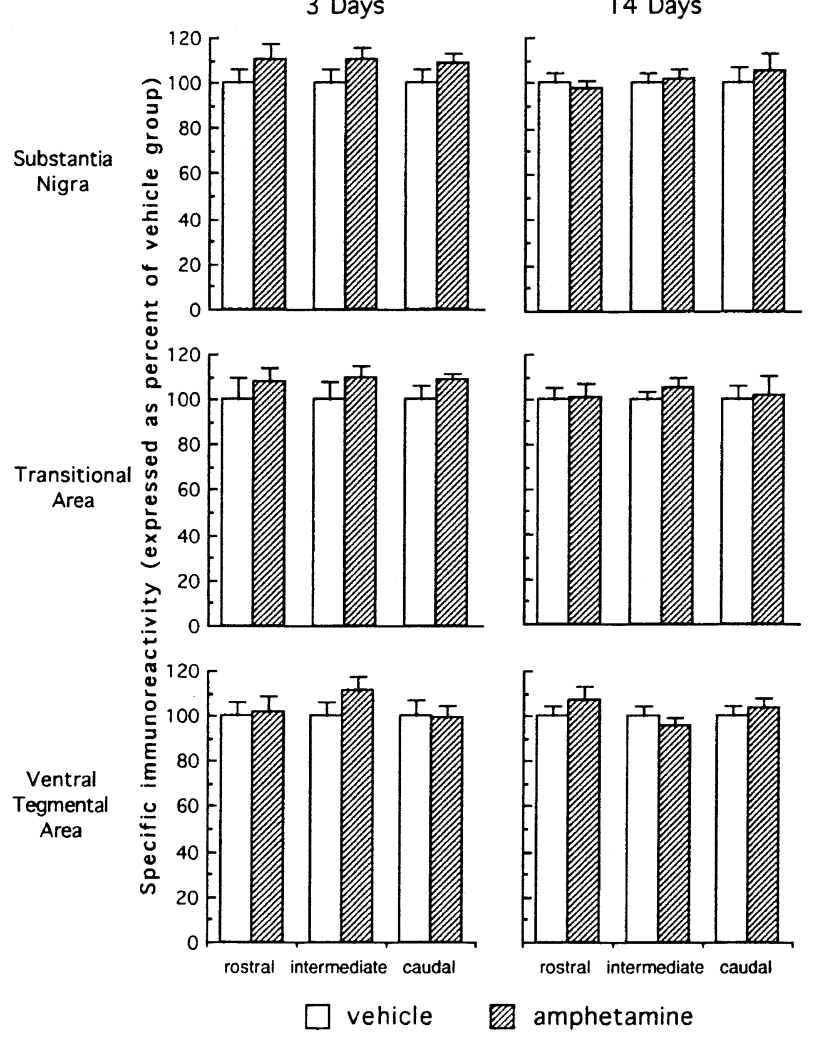

Figure 4. Levels of GluR1 immunolabeling in rat midbrain did not differ significantly between saline-and amphetamine-pretreated groups at three or 14 day withdrawal times. Autoradiographs were analyzed quantitatively using $\mathrm{NIH}$ Image software. For each rat, nine subregions of the ventral midbrain (VTA, substantia nigra, and a transitional area; each at rostral, intermediate and caudal levels) were analyzed by scanning both right and left sides of 2-3 coronal sections (see Materials and Methods). The bars represent the mean of such determinations from 8-10 rats in each pretreatment group. In this and all subsequent figures, data are presented as percentage of the appropriate saline control group, i.e., the amphetamine/three day withdrawal group is compared to the saline/three day withdrawal group. Groups were compared with a two-tailed Student's t test $\left({ }^{*} p<.05\right)$.

scribed above for immunohistochemical studies. One microgram of total RNA from VTA was reverse transcribed with increasing amounts of pGluR1 $\Delta$ (10 fg to 1 $\mathrm{pg}$ ) and then co-amplified in the presence of radiolabeled primer for 32 cycles of amplification. The incorporation of radioactivity in the PCR products was quantified with a PhosphorImager. The data obtained were plotted as the log [target/competitor] versus log of the amount of competitor added to the PCR reaction. The molar amount of endogenous GluR1 mRNA added to the reaction is equal to the molar amount of competitor when the ratio of their products becomes equal (log ratio 1:1 =0). This "zero-point" was calculated by re- gression analysis for each group. Results from three independent experiments were averaged, normalized to the saline control group, and expressed as mean \pm SEM (repeated saline, $100 \pm 5 \%$; repeated amphetamine, $105 \pm$ $4 \%$; repeated cocaine, $95 \pm 3 \%$ ). ANOVA performed on raw data indicated no significant difference between the groups. Thus, repeated cocaine or amphetamine administration does not alter GluR1 mRNA levels in the VTA as determined by RT-PCR.

\section{DISCUSSION}

Repeated amphetamine administration did not alter GluR1, GluR2, GluR2/3, or GluR4 immunolabeling in the VTA, SN, or a transitional zone as measured by autoradiographic immunohistochemical methods at three or 14-day withdrawal times. At earlier withdrawal times (16-24 hrs), neither GluR1 immunolabeling nor GluR1 mRNA levels (determined by RT-PCR) were significantly altered by repeated cocaine or amphetamine administration.

\section{AMPA Receptor Subunit Distribution in Midbrain}

We observed moderate levels of GluR1 and GluR2 and lower levels of GluR2/3 and GluR4 immunolabeling throughout the midbrain. Other immunohistochemical studies of the rat substantia nigra and VTA have found moderate GluR1 and GluR2/3 immunoreactivity in neurons, with GluR4 observed primarily in neuropil (Petralia and Wenthold 1992; Martin et al. 1993; Jakowec et al. 1998). In situ hybridization studies have found low to moderate levels of GluR1, GluR2 and GluR4 mRNAs and very low levels of GluR3 mRNA (Sato et al. 1993; Jakowec et al. 1998). A recent study in rat substantia nigra found that all tyrosine hydroxylase (TH)-positive cells also contained GluR2/3 immunoreactivity, none contained GluR4, and GluR1 expression was heterogeneous, with about half of the cells staining intensely and the other half immunonegative (Albers et al. 1999). In squirrel monkey, nearly all TH-positive neurons in the midbrain contained GluR1, GluR2/3, and GluR4 immunoreactivity (Paquet et al. 1997).

\section{Electrophysiological Supersensitivity Is Unlikely to Reflect a Generalized Increase in AMPA Receptor Expression in the VTA}

Electrophysiological studies have shown that both NMDA and AMPA receptor agonists increase the firing rate of VTA and SN DA neurons (White 1996). Following repeated amphetamine or cocaine administration, VTA DA neurons show a selective increase in responsiveness to AMPA (White et al. 1995; Zhang et al. 1997). Like most other stimulant-induced neuroadaptations 
Table 1. Immunolabeling of AMPA Receptor Subunits in Rat Midbrain after 3 or 14 Days Withdrawal from Repeated Amphetamine Administration

\begin{tabular}{|c|c|c|c|c|c|c|}
\hline & & & Three & Withdrawal & $14 \mathrm{D}$ & Vithdrawal \\
\hline & & & Vehicle & Amphetamine & Vehicle & Amphetamine \\
\hline GluR2 & Substantia & Rostral & $100 \pm 4.5$ & $97.6 \pm 6.3$ & $100 \pm 3.8$ & $90.4 \pm 4.3$ \\
\hline & Nigra & Intermediate & $100 \pm 5.8$ & $99.0 \pm 6.3$ & $100 \pm 3.3$ & $96.5 \pm 3.9$ \\
\hline & & Caudal & $100 \pm 6.7$ & $86.4 \pm 3.4$ & $100 \pm 4.5$ & $92.8 \pm 4.8$ \\
\hline & Transitional & Rostral & $100 \pm 7.4$ & $101.2 \pm 7.1$ & $100 \pm 3.2$ & $99.1 \pm 3.4$ \\
\hline & Area & Intermediate & $100 \pm 5.8$ & $99.4 \pm 7.8$ & $100 \pm 2.5$ & $97.7 \pm 4.4$ \\
\hline & & Caudal & $100 \pm 6.0$ & $85.7 \pm 4.6$ & $100 \pm 5.1$ & $90.8 \pm 4.6$ \\
\hline & Ventral & Rostral & $100 \pm 7.0$ & $101.8 \pm 5.8$ & $100 \pm 3.2$ & $94.1 \pm 3.7$ \\
\hline & Tegmental & Intermediate & $100 \pm 6.2$ & $100.5 \pm 8.2$ & $100 \pm 4.4$ & $93.5 \pm 4.1$ \\
\hline & Area & Caudal & $100 \pm 3.8$ & $102.1 \pm 4.5$ & $100 \pm 3.6$ & $94.6 \pm 4.3$ \\
\hline GluR2/3 & Substantia & Rostral & $100 \pm 8.7$ & $94.3 \pm 5.5$ & $100 \pm 5.0$ & $102.0 \pm 6.0$ \\
\hline & Nigra & Intermediate & $100 \pm 10.2$ & $97.1 \pm 5.5$ & $100 \pm 5.4$ & $91.7 \pm 3.8$ \\
\hline & & Caudal & $100 \pm 9.4$ & $87.4 \pm 5.8$ & $100 \pm 5.9$ & $92.9 \pm 4.5$ \\
\hline & Transitional & Rostral & $100 \pm 10.3$ & $98.2 \pm 6.5$ & $100 \pm 8.3$ & $101.6 \pm 6.2$ \\
\hline & Area & Intermediate & $100 \pm 9.4$ & $96.0 \pm 6.2$ & $100 \pm 5.7$ & $95.4 \pm 3.6$ \\
\hline & & Caudal & $100 \pm 7.4$ & $93.5 \pm 6.3$ & $100 \pm 6.6$ & $93.6 \pm 4.2$ \\
\hline & Ventral & Rostral & $100 \pm 6.5$ & $95.8 \pm 4.9$ & $100 \pm 5.0$ & $101.9 \pm 6.1$ \\
\hline & Tegmental & Intermediate & $100 \pm 4.5$ & $90.7 \pm 3.9$ & $100 \pm 3.6$ & $90.8 \pm 5.1$ \\
\hline & Area & Caudal & $100 \pm 4.9$ & $99.5 \pm 8.1$ & $100 \pm 3.6$ & $89.9 \pm 4.2$ \\
\hline GluR4 & Substantia & Rostral & $100 \pm 4.7$ & $97.5 \pm 3.7$ & $100 \pm 3.1$ & $90.4 \pm 3.9$ \\
\hline & Nigra & Intermediate & $100 \pm 4.9$ & $93.7 \pm 4.0$ & $100 \pm 3.9$ & $98.8 \pm 5.0$ \\
\hline & & Caudal & $100 \pm 4.4$ & $96.1 \pm 4.8$ & $100 \pm 3.6$ & $95.2 \pm 2.7$ \\
\hline & Transitional & Rostral & $100 \pm 6.3$ & $101.4 \pm 3.5$ & $100 \pm 5.0$ & $97.8 \pm 3.8$ \\
\hline & Area & Intermediate & $100 \pm 5.4$ & $94.6 \pm 2.9$ & $100 \pm 4.7$ & $107.5 \pm 4.6$ \\
\hline & & Caudal & $100 \pm 5.1$ & $96.0 \pm 4.5$ & $100 \pm 3.3$ & $100.7 \pm 2.8$ \\
\hline & Ventral & Rostral & $100 \pm 6.5$ & $99.6 \pm 4.5$ & $100 \pm 6.0$ & $106.3 \pm 3.6$ \\
\hline & Tegmental & Intermediate & $100 \pm 5.9$ & $102.9 \pm 8.1$ & $100 \pm 4.6$ & $104.8 \pm 4.0$ \\
\hline & Area & Caudal & $100 \pm 8.1$ & $101.3 \pm 5.5$ & $100 \pm 8.7$ & $106.5 \pm 5.1$ \\
\hline
\end{tabular}

For each rat, nine subregions of ventral midbrain (VTA, SN, and transitional area; each at rostral, intermediate and caudal levels) were analyzed. Data from 8-9 rats/group are presented as percentage of the appropriate saline control group.

occurring at the level of the VTA, increased responsiveness to AMPA is transient, detectable after three but not 14 days of withdrawal (Zhang et al. 1997). Recently, we have shown that AMPA receptor supersensitivity can also be demonstrated in microdialysis experiments, by monitoring the ability of intra-VTA AMPA to increase DA levels in the ipsilateral nucleus accumbens. After three days but not 10-14 days of withdrawal, AMPA was more efficacious in amphetamine treated rats than saline treated rats (Giorgetti et al. 2001).

Although increased AMPA receptor expression is a plausible explanation for increased responsiveness to AMPA, we did not detect a significant change in AMPA receptor subunit expression in VTA at either three or 14 day withdrawal times using the same amphetamine regimen employed in the electrophysiological studies (White et al. 1995; Zhang et al. 1997) and microdialysis studies (Giorgetti et al. 2001). Since about $65 \%$ of cells in the rat VTA are dopaminergic (Swanson 1982), it seems unlikely that a selective increase in AMPA receptor subunit expression within DA neurons would be completely masked by the signal from non-DA cells. Indeed, an immunohistochemical approach was chosen to avoid concerns about "contamination" due to the proximity of other regions that contain high levels of GluR subunits (e.g., the interpeduncular nucleus). In addition, we analyzed nine subregions of midbrain to insure that changes occurring in one region would not be obscured by lack of effect in others. However, without double labeling and single cell analysis, we cannot rule out the possibility that we failed to detect a change in GluR labeling that was selective for DA neurons.

Fitzgerald et al. (1996) found an increase in GluR1 levels in VTA, using Western blotting, in rats killed 16$18 \mathrm{hrs}$ after discontinuation of repeated cocaine, morphine, or stress paradigms. Another Western blotting study found increased GluR1 in VTA $24 \mathrm{hrs}$ but not three weeks after discontinuing a different cocaine regimen (Churchill et al. 1999). Although we found no statistically significant changes in GluR1 either three or 14 days after discontinuation of repeated amphetamine, there was a slight trend towards increased GluR1 in some midbrain subregions at the three-day time. This raised the possibility that amphetamine, like cocaine and morphine (above), produced an increase in GluR1 at the 16-18 hrs withdrawal time, which dissipated substantially by three days of withdrawal but nevertheless remained functionally significant. We therefore exam- 


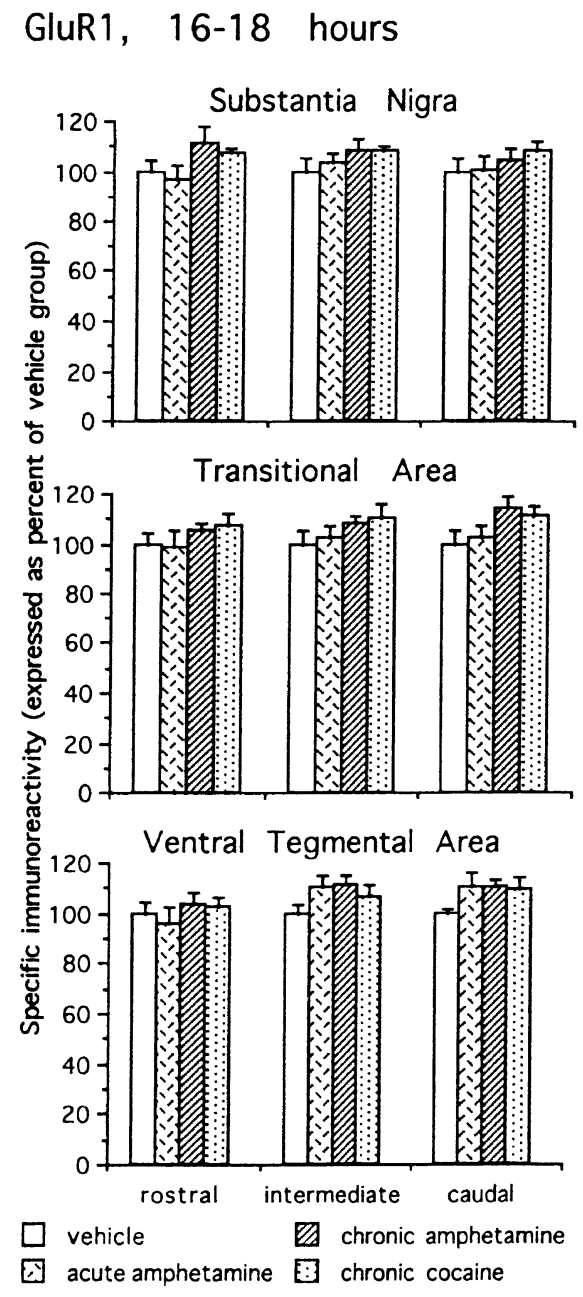

Figure 5. GluR1 immunolabeling in rat midbrain measured 16-18 hrs after the last injection is not altered by acute amphetamine, repeated amphetamine or repeated cocaine administration. Groups received saline $(1 \mathrm{ml} / \mathrm{kg} \times 6$ days $)$, a single amphetamine injection (saline $\times 4$ days, $5 \mathrm{mg} / \mathrm{kg}$ amphetamine on Day 5), repeated amphetamine $(5 \mathrm{mg} / \mathrm{kg} /$ day $\times 5$ days), or repeated cocaine $(20 \mathrm{mg} / \mathrm{kg} /$ day $\times 7$ days $)$. See legend to Figure 4 for details of analysis; $n=10$ rats/group.

ined 16-18 hrs and $24 \mathrm{hrs}$ withdrawal times and still found no change in GluR1 immunolabeling.

Taken alone, this might suggest that amphetamine is different from cocaine and morphine. Surprisingly, however, we also failed to observe increased GluR1 levels $16-18 \mathrm{hrs}$ or $24 \mathrm{hrs}$ after discontinuation of the same cocaine regimen employed by Fitzgerald et al. (1996). While there were trends towards increased GluR1 in chronic cocaine and amphetamine groups at the 16-18 hrs withdrawal, they were not confined to VTA and similar trends were observed in an acute amphetamine group. These results are quite different from those of the previous study (Fitzgerald et al. 1996), in which increased GluR1 was observed in VTA but not substantia nigra, and was not produced by acute drug exposure.

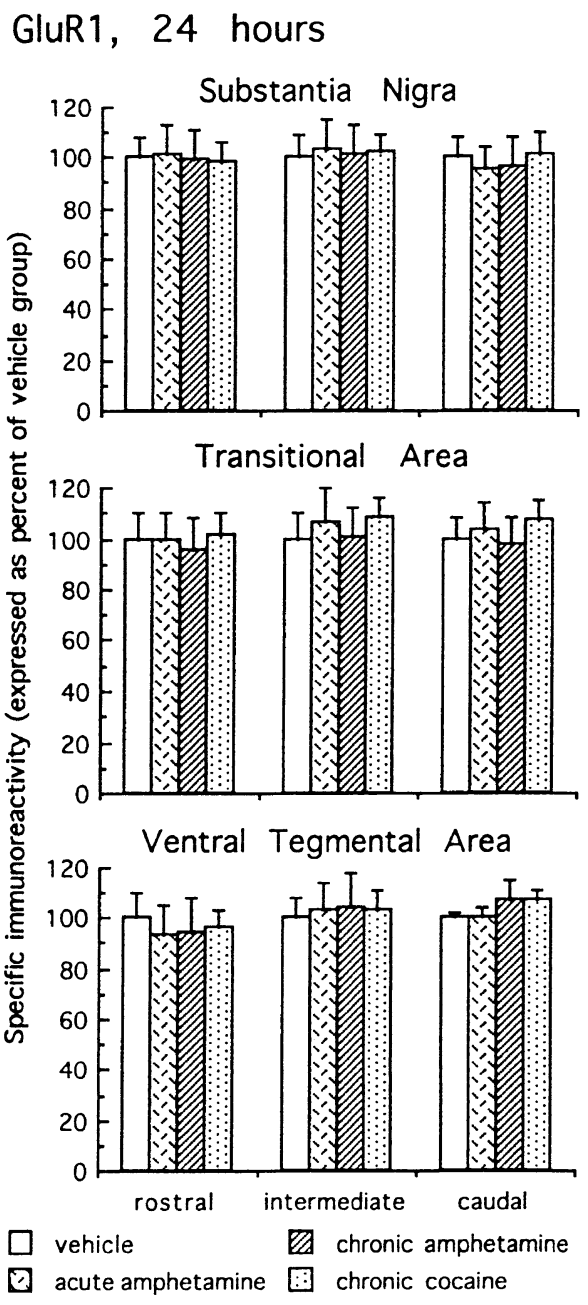

Figure 6. GluR1 immunolabeling in rat midbrain measured $24 \mathrm{hrs}$ after the last injection is not altered by acute amphetamine, repeated amphetamine or repeated cocaine administration. Groups received repeated saline $(1 \mathrm{ml} / \mathrm{kg} \times 6$ days), a single amphetamine injection (saline $\times 4$ days, $5 \mathrm{mg} / \mathrm{kg}$ amphetamine on Day 5), repeated amphetamine $(5 \mathrm{mg} / \mathrm{kg} /$ day $\times 5$ days), or repeated cocaine $(20 \mathrm{mg} / \mathrm{kg} /$ day $\times 7$ days). See legend to Figure 4 for details of analysis; $n=10$ rats/group.

The trends apparent in our 16-18 hrs withdrawal experiment were largely absent in identically treated rats killed at a slightly longer withdrawal time ( $24 \mathrm{hrs})$. Finally, RT-PCR studies found no change in the abundance of GluR1 mRNA in VTA tissue obtained 16-18 hrs after discontinuation of the same cocaine and amphetamine regimens. Levels of mRNA for the ionotropic glutamate receptor subunits generally correlate with the abundance of the encoded subunits (Lambolez et al. 1992; Bochet et al. 1994; Jonas et al. 1994; Geiger et al. 1995; Angulo et al. 1997). It should be noted that GluR1 and other AMPA receptor subunits exist as two isoforms, flip and flop, that are generated by alternative splicing and have different functional properties (Sommer et al. 1990). As our amplification strategy did not 


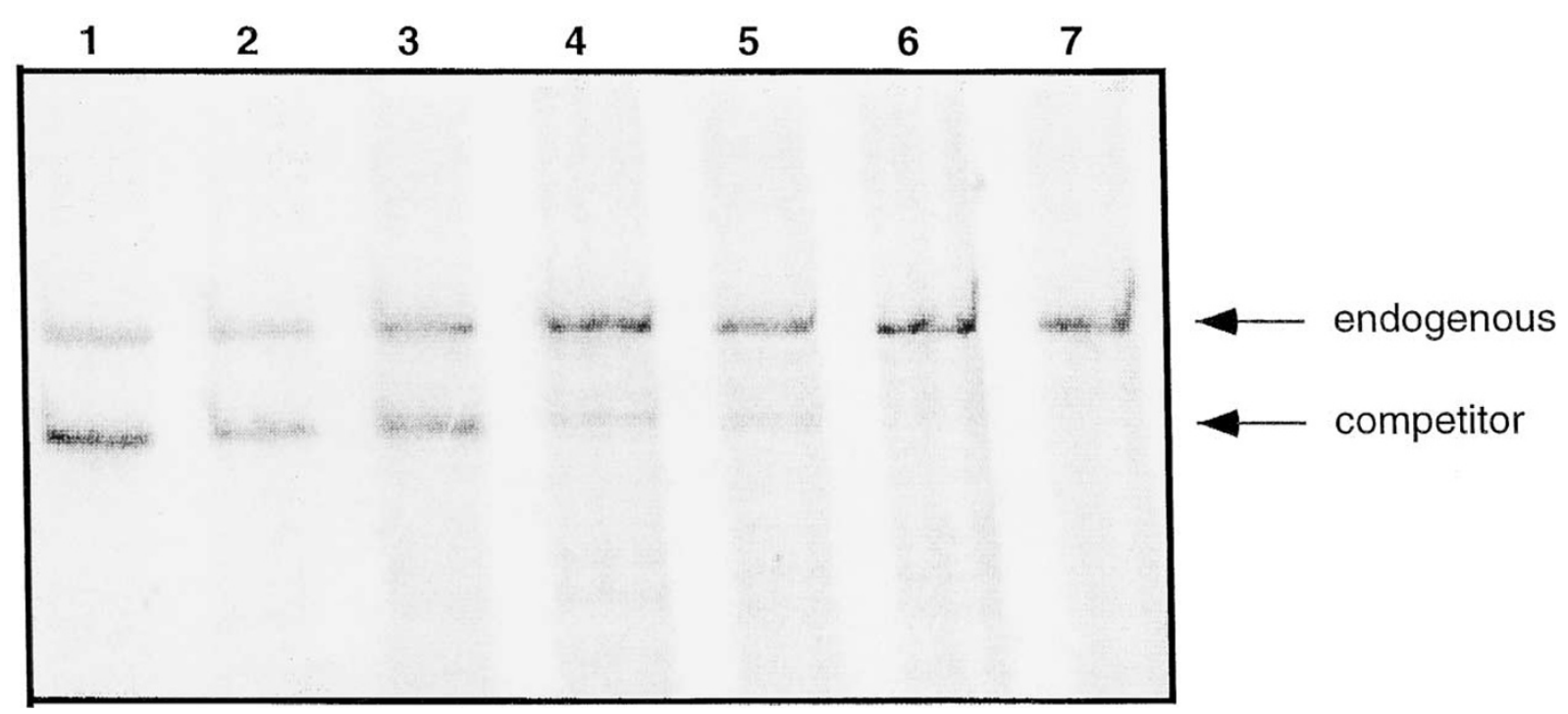

Figure 7. PhosphorImager analysis of GluR1 PCR competition experiments from the VTA after 32 cycles. Lane 1: 10 pg pGluR1s, Lane 2: 3 pg pGluR1s, Lane 3: 1 pg pGluR1s, Lane 4: 300 fg pGluR1s, Lane 5: 100 fg pGluR1s, Lane 6: 10 fg pGluR1s, and Lane 7: $0 \mathrm{fg}$ pGluR1 . GluR1 PCR products were electrophoresed through an 8\% polyacrylamide gel. The incorporation of radioactivity was detected using a PhosphorImager (Molecular Dynamics).

distinguish between these isoforms, our results do not exclude the possibility that cocaine and amphetamine may alter the ratio of these isoforms.

The reason for the discrepancy between our results and those of others. (Fitzgerald et al. 1996; Churchill et al. 1999) is not clear, but it is unlikely to be attributable to inadequate sensitivity of our methods. The magnitude of the chronic cocaine-induced increase in GluR1 detected by Fitzgerald et al. (1996) was on the order of $45 \%$. Using the same immunohistochemical techniques employed in the present study, we have detected much smaller changes in GluR1 and GluR2 immunolabeling $(\sim 15 \%)$ in other brain regions after repeated amphetamine administration (Lu and Wolf 1999). These brain regions showed parallel amphetamine-induced changes in GluR1 and GluR2 mRNA levels (Lu et al. 1997). In the midbrain, we have used this technique to detect decreases of approximately 15\% in NMDAR1 immunolabeling in intermediate and caudal regions of the substantia nigra after 14 days of withdrawal from repeated amphetamine ( $\mathrm{Lu}$ et al. 1999). In that study, no changes in NMDAR1 were evident in the substantia nigra after three days of withdrawal, or in the VTA at either withdrawal time.

It is possible that the discrepancy is related to methodological differences. Although the same polyclonal antibody was used in all studies, significant increases in GluR1 could be masked in immunohistochemical experiments if the primary antibody recognized antigens other than GluR1 in tissue sections. However, we found that preadsorption with the synthetic peptide used to generate the anti-GluR1 antibody completely eliminated specific GluR1 immunolabeling. Another poten- tial explanation for the discrepancy is that different pools of GluR1 are detected by the present immunohistochemical methods and by Western blot analysis after proteins are electrophoresed in a denaturing gel (Fitzgerald et al. 1996; Churchill et al. 1999). Precedent for this possibility comes from studies showing that conformational changes associated with altered subcellular localization of the glucose transporter 4 can dramatically and differentially influence Western blot and immunocytochemical analyses of this protein (Joost et al. 1988; Smith et al. 1991, 1993). However, the anti-GluR1 antibody detects GluR1 in a number of cellular compartments (e.g., Martin et al. 1993; Chen et al. 1998; Paquet et al. 1997). Most importantly, the type of change in GluR1 disposition most likely to explain enhanced electrophysiological responsiveness, that is, an increase in cell surface expression, should be detectable with immunohistochemical methods.

Additional impetus for the hypothesis that increased GluR1 expression contributes to sensitization was provided by the report that over-expression of GluR1 in the rostral VTA using a Herpes simplex virus resulted in intensification of the locomotor stimulant and rewarding properties of morphine (Carlezon et al. 1997, 2000). While this is an interesting finding, it does not necessarily imply that increased GluR1 expression is involved in the naturally occurring pathways leading to morphine or psychostimulant sensitization. Indeed, a state resembling behavioral sensitization can be produced by a diverse array of experimental manipulations that share the ability to produce brief but intense activation of VTA DA cells. These include repeated electrical stimulation of the prefrontal cortex (Schenk and Snow 1994) or VTA (Ben- 
Shahar and Ettenberg 1994), and pharmacological disinhibition of VTA DA cells (Steketee and Kaliavas 1991).

In a prior Western blotting study, it was observed that only those rats developing behavioral sensitization to cocaine exhibited an increase in GluR1 levels in the VTA (Churchill et al. 1999). In the present study, we did not perform behavioral studies to verify that sensitization occurred in our repeated amphetamine or cocaine treatment groups. However, it seems unlikely that failure of a subset of rats to develop sensitization accounts for the observed lack of increase in GluR1 levels. The amphetamine regimen used in these studies produces reliable and robust sensitization (e.g., Wolf and Jeziorski 1993). Moreover, it is our experience that amphetamine, in contrast to cocaine, produces behavioral sensitization in all or nearly all rats.

\section{Alternative Mechanisms to Account for Increased Responsiveness of VTA DA Neurons to AMPA}

We have hypothesized that drug-induced plasticity in the VTA involves activity-dependent changes in synaptic strength (Wolf 1998). Indeed, recent studies have shown that VTA DA neurons undergo both LTP and LTD (Bonci and Malenka 1999; Overton et al. 1999) and that acute exposure to amphetamine (Jones et al. 2000) or D2 DA agonists (Thomas et al. 2000) can prevent the induction of LTD. It is therefore reasonable to consider the possibility that the increased AMPA receptor responsiveness produced by drugs of abuse occurs through mechanisms similar to those implicated in LTP and LTD.

A novel hypothesis for LTP and LTD involves silent synapses, which contain functional NMDA receptors but not functional AMPA receptors. LTP may involve activation of silent synapses via recruitment of AMPA receptors, whereas LTD may involve loss of functional AMPA receptors (Malenka and Nicoll 1997). Increased responsiveness of VTA DA neurons to AMPA might similarly reflect an increase in the number of AMPA receptor-containing synapses. This would not necessarily be detectable by immunohistochemical or Western analysis at the regional level. For example, insulininduced LTD involves loss of surface AMPA receptors via acceleration of clathrin-dependent endocytosis but is not associated with a change in the total number of receptors expressed by the cells (Man et al. 2000).

Another possibility is that AMPA receptor transmission is enhanced by phosphorylation of GluR1. GluR1 is phosphorylated on the carboxyl terminus by $\mathrm{Ca}^{2+} / \mathrm{cal}-$ modulin-dependent protein kinase type II (CaMKII), protein kinase $\mathrm{C}$, and protein kinase $\mathrm{A}$, with phosphorylation resulting in potentiation of agonist-activated currents (e.g., Roche et al. 1996; Barria et al. 1997a; Mammen et al. 1997; Derkach et al. 1999; Banke et al. 2000). Phosphorylation of GluR1 by CaMKII is strongly implicated in long-term potentiation (LTP) (Barria et al. 1997b) whereas dephosphorylation of GluR1 at the protein kinase A site accompanies long-term depression (LTD) (Lee et al. 1998). Although the effects of amphetamine and cocaine on GluR1 phosphorylation in the VTA are not known, D1 DA receptors regulate GluR1 phosphorylation in striatum and nucleus accumbens (Chao et al. 1999; Price et al. 1999; Yan et al. 1999) and D1 receptors in the VTA are implicated in sensitization (Stewart and Vezina 1989; Bjijou et al. 1996; Vezina 1996).

\section{CONCLUSIONS}

Many lines of evidence suggest that a critical step in the induction of behavioral sensitization is a transient increase in VTA DA cell activity (White 1996; Wolf 1998). Previous studies suggest that one contributing mechanism is enhanced sensitivity of AMPA receptors on VTA DA neurons to the excitatory effects of glutamate (White et al. 1995; Zhang et al. 1997; Giorgetti et al. 2001). The present results indicate that this enhanced sensitivity is probably not attributable to an overall increase in the expression of AMPA receptor subunits and suggest the need for studies to determine whether repeated administration of psychomotor stimulants influences the cell surface distribution or phosphorylation of AMPA receptor subunits.

\section{Note Added in Proof}

A recently published study measured GluR1-4 mRNA levels using ribonuclease protection assays in the ventral mesencephalon of rats killed $30 \mathrm{~min}$ after the third or tenth daily injection of $2 \mathrm{mg} / \mathrm{kg}$ amphetamine and found no difference between amphetamine treated rats and saline controls (Bardo et al. 2001)

\section{ACKNOWLEDGMENTS}

Drs. Lu and Monteggia contributed equally to this study. We are grateful to Drs. Stephen Heinemann and Jim Boulter for providing rat GluR1 cDNA and to Dr. Robert J. Wenthold for providing the BSA-conjugated form of the peptide used to raise the GluR1 antibody. We also thank Dr. Jean-Marc Roch for advice on competitive PCR experiments, and Chang-Jiang Xue and Dr. Christy Stine for assistance with some procedures. Supported by USPHS grants DA09621 and DA00453 to MEW.

\section{REFERENCES}

Ackerman JM, White FJ (1990): A10 somatodendritic dopamine autoreceptor sensitivity following withdrawal from repeated cocaine treatment. Neurosci Lett 117:181-187

Albers DS, Weiss SW, Iadarola MJ, Standaert DG (1999): Immunohistochemical localization of N-methyl-D-aspartate and $\alpha$-amino-3-hydroxyl-5-methyl-4-isoxazolepropionate receptor subunits in the substantia nigra pars compacta of the rat. Neurosci 89:209-220

Angulo MC, Lambolez B, Audinat E, Hestrin S, Rossier J 
(1997): Subunit composition, kinetic, and permeation properties of AMPA receptors in single neocortical nonpyramidal cells. J Neurosci 17:6685-6696

Banke TG, Bowie D, Lee H-K, Huganir RL, Schousboe A, Traynelis SF (2000): Control of GluR1 AMPA receptor function by cAMP-dependent protein kinase. J Neurosci 20:89-102

Bardo MT, Robinet PM, Mattingly BA, Margulies JE (2001): Effect of b-hydroxydopamine or repeated amphetamine treatment on mesencephamine mRNA levels for AMPA glutamate receptor subunits in the rat. Neurosci Lett 302:133-136

Barria A, Derkach V, Soderling T (1997a): Identification of the $\mathrm{Ca}^{2+}$ / calmodulin-dependent protein kinase II regulatory phosphorylation site in the $\alpha$-amino-3-hydroxyl5-methyl-4-isoxazole-propionate-type glutamate receptor. J Biol Chem 272:32727-32730

Barria A, Muller D, Derkach V, Griffith LC, Soderling TR (1997b): Regulatory phosphorylation of AMPA-type glutamate receptors by CaM-KII during long-term potentiation. Science 276:2042-2045

Ben-Shahar O, Ettenberg A (1994): Repeated stimulation of the ventral tegmental area sensitizes the hyperlocomotor response to amphetamine. Pharmacol Biochem Behav 48: 1005-1009

Bjijou Y, Stinus L, Le Moal M, Cador M (1996): Evidence for selective involvement of dopamine $D_{1}$ receptors of the ventral tegmental area in the behavioral sensitization induced by intra-ventral tegmental area injections of D-amphetamine. J Pharmacol Exp Ther 277:1177-1187

Bochet P, Audinat E, Lambolez B, Crépel F, Rossier J, Iino M, Tsuzuki K, Ozawa S (1994): Subunit composition at the single-cell level explains functional properties of a glutamate-gated channel. Neuron 12:383-388

Bonci A, Malenka RC (1999): Properties and plasticity of excitatory synapses on dopaminergic and GABAergic cells in the ventral tegmental area. J Neurosci 19:3723-3730

Carlezon WA Jr, Boundy VA, Haile CN, Lane SB, Kalb RG, Neve RL, Nestler EJ (1997): Sensitization to morphine induced by viral-mediated gene transfer. Science 277:812-814

Carlezon WA Jr, Haile CN, Coopersmith R, Hayashi Y, Malinow R, Neve RL, Nestler EJ (2000): Distinct sites of opiate reward and aversion within the midbrain identified using a Herpes Simplex virus vector expressing GluR1. J Neurosci 220:RC62:1-5

Chao SZ, Lu WX, Lee HK, Huganir RL, Wolf ME (1999): D1 dopamine receptor stimulation increases GluR1 phosphorylation in postnatal nucleus accumbens cultures. Soc Neurosci Abstr 25:2211

Chen Q, Veenman L, Knopp K, Yan Z, Medina L, Song W-J, Surmeier DJ, Reiner A (1998): Evidence for the preferential localization of glutamate receptor-1 subunits of AMPA receptors to the dendritic spines of medium spiny neurons in rat striatum. Neurosci 83:749-761

Chomczynski P, Sacchi N (1987): A single step method for the isolation of RNA using the acid-phenol-chloroform method. Anal Biochem 162:156-159

Churchill L, Swanson CJ, Urbina M, Kalivas PW (1999): Repeated cocaine alters glutamate receptor subunit levels in the nucleus accumbens and ventral tegmental area of rats that develop behavioral sensitization. J Neurochem 72:2397-2403
Derkach V, Barria A, Soderling TR (1999): $\mathrm{Ca}^{2+}$-calmodulinkinase II enhances channel conductance of $\alpha$-amino3-hydroxy-5-methy-4-isoxazolepropionate type glutamate receptors. Proc Natl Acad Sci USA 96:3269-3274

Fitzgerald LW, Ortiz J, Hamedani AG, Nestler EJ (1996): Drugs of abuse and stress increase the expression of GluR1 and NMDAR1 glutamate receptor subunits in the rat ventral tegmental area: Common adaptations among cross-sensitizing agents. J Neurosci 16:274-282

Geiger JRP, Melcher T, Koh D-S, Sakmann B, Seeburg PH, Jonas P, Monyer H (1995): Relative abundance of subunit mRNAs determines gating and $\mathrm{Ca}^{2+}$ permeability of AMPA receptors in principal neurons and interneurons in rat CNS. Neuron 15:193-204

Giorgetti M, Hotsenpiller G, Ward P, Teppen T, Wolf ME (2001): Amphetamine-induced plasticity of AMPA receptors in the ventral tegmental area: Effects on extracellular levels of dopamine and glutamate in freely moving rats. J Neurosci, 21:6362-6369

Jakowec MW, Jackson-Lewis V, Chen X, Langston JW, Przedborski S (1998): The postnatal development of AMPA receptor subunits in the basal ganglia of the rat. Dev Neurosci 20:19-33

Joost HG, Weber TM, Cushman SW (1988): Qualitative and quantitative comparison of glucose transport activity and glucose transporter concentration in plasma membranes from basal and insulin-stimulated rat adipose cells. Biochem J 249:155-161

Jonas P, Racca C, Sakmann B, Seeburg PH, Monyer H (1994): Differences in $\mathrm{Ca}^{2+}$ permeability of AMPA-type glutamate receptor channels in neocortical neurons caused by differential GluR-B subunit expression. Neuron 12:1281-1289

Jones S, Kornblum JL, Kauer JA (2000): Amphetamine blocks long-term synaptic depression in the ventral tegmental area. J Neurosci 20:5575-5580

Kalivas PW, Stewart J (1991): Dopamine transmission in the initiation and expression of drug- and stress-induced sensitization of motor activity. Brain Res Rev 16:223-244

Lambolez B, Audinat E, Bochet P, Crépel F, Rossier J (1992): AMPA receptor subunits expressed by single Purkinje cells. Neuron 9:247-258

Lee H-K, Kameyama K, Huganir RL, Bear MF (1998): NMDA induces long-term synaptic depression and dephosphorylation of the GluR1 subunit of AMPA receptors in hippocampus. Neuron 21:1151-1162

Li Y, White FJ, Wolf ME (2000): Pharmacological reversal of behavioral and cellular indices of cocaine sensitization. Psychopharmacology 151:175-183

Lu W, Chen H, Xue C-J, Wolf ME (1997): Repeated amphetamine administration alters the expression of mRNA for AMPA receptor subunits in rat nucleus accumbens and prefrontal cortex. Synapse 26:269-280

Lu W, Monteggia LM, Wolf ME (1999): Withdrawal from repeated amphetamine administration reduces NMDAR1 expression in the rat substantia nigra, nucleus accumbens and medial prefrontal cortex. Eur J Neurosci 11:3167-3177

Lu W, Wolf ME (1999): Repeated amphetamine administration alters immunoreactivity for AMPA receptor subunits in rat nucleus accumbens and medial prefrontal cortex. Synapse 32:119-131 
Malenka RC, Nicoll RA (1997): Silent synapses speak up. Neuron 19:473-476

Mammen AL, Kameyama K, Roche KW, Huganir RL (1997): Phosphorylation of the $\alpha$-amino-3-hydroxy-5-methylisoxazole-4-propionic acid receptor GluR1 subunit by calcium/calmodulin-dependent kinase II. J Biol Chem 272:32528-32533

Man H-Y, Lin JW, Ju WH, Ahmadian G, Liu L, Becker LE, Sheng M, Wang Y-T (2000): Regulation of AMPA receptor-mediated synaptic transmission by clathrin-dependent receptor internalization. Neuron 25:649-662

Martin LJ, Blackstone CD, Levey AI, Huganir RL, Price DL (1993): AMPA glutamate receptor subunits are differentially distributed in rat brain. Neuroscience 53:327-358

Ortiz J, Fitzgerald LW, Charlton M, Lane S, Trevisan L, Guitart X, Shoemaker W, Duman RS, Nestler EJ (1995): Biochemical actions of chronic ethanol exposure in the mesolimbic dopamine system. Synapse 21:289-298

Overton PG, Richards CD, Berry MS, Clark D (1999): Longterm potentiation at excitatory amino acid synapses on midbrain dopamine neurons. Neuroreport 10:221-226

Paquet M, Tremblay M, Soghomonian J-J, Smith Y (1997): AMPA and NMDA glutamate receptor subunits in midbrain dopaminergic neurons in the squirrel monkey: An immunohistochemical and in situ hybridization study. J Neurosci 17:1377-1396

Paxinos G, Watson C (1986): The Rat Brain in Stereotaxic Coordinates. San Diego, Academic Press

Petralia RS, Wenthold RJ (1992): Light and electron immunocytochemical localization of AMPA-selective glutamate receptors in the rat brain. J Comp Neurol 318:329-354

Price CJ, Kim P, Raymond LA (1999): D1 dopamine receptorinduced cyclic AMP-dependent protein kinase phosphorylation and potentiation of striatal glutamate receptors. J Neurochem 73:2441-2446

Robinson TE, Berridge KC (1993): The neural basis of drug craving: An incentive-sensitization theory of addiction. Brain Res Rev 18:247-291

Roche KW, O’Brien RJ, Mammen AL, Bernhardt J, Huganir RL (1996): Characterization of multiple phosphorylation sites on the AMPA receptor GluR1 subunit. Neuron 16:1179-1188

Sato K, Kiyama H, Tohyama M (1993): The differential expression patterns of messenger RNAs encoding non$\mathrm{N}$-methyl-D-aspartate receptor subunits (GluR1-4) in the rat brain. Neuroscience 52:515-539

Schenk S, Snow S (1994): Sensitization to cocaine's motor activating properties produced by electrical kindling of the medial prefrontal cortex but not of the hippocampus. Brain Res 659:17-22

Smith RM, Charron MJ, Shah NS, Lodish HF, Jarett L (1991): Immunoelectron microscopic demonstration of insulinstimulated translocation of glucose transporters to the plasma membrane of isolated rat adipocytes and masking of the carboxyl-terminal epitope of intracellular GLUT4. Proc Natl Acad Sci U S A 88:6893-6897

Smith RM, Tiesinga JJ, Shah N, Smith JA, Jarett L (1993): Genistein inhibits insulin-stimulated glucose transport and decreases immunocytochemical labeling of GLUT4 carboxyl-terminus without affecting translocation of GLUT4 in isolated rat adipocytes: Additional evidence of GLUT4 activation by insulin. Arch Biochem Biophys 300:238-246

Sommer B, Keinanen K, Verdoorn TA, Wisden W, Burnashev N, Herb A, Kohler M, Takagi T, Sakmann B, Seeburg PH (1990): Flip and flop: A cell-specific functional switch in glutamateoperated channels of the CNS. Science 249: 1580-1585

Steketee JD, Kalivas PW (1991): Sensitization to psychostimulants and stress after injection of pertussis toxin into the A10 dopamine region. J Pharmacol Exp Ther 259: 916-924

Stewart J, Vezina P (1989): Microinjections of Sch-23390 into the ventral tegmental area and substantia nigra pars reticulata attenuate the development of sensitization to the locomotor activating effects of systemic amphetamine. Brain Res 495:401-406

Swanson LW (1982): The projections of the ventral tegmental area and adjacent regions: A combined fluorescent retrograde tracer and immunofluorescence study in the rat. Brain Res Bull 9:321-353

Thomas MJ, Malenka RC, Bonci A (2000): Modulation of long-term depression by dopamine in the mesolimbic system. J Neurosci 20:5581-5586

Vanderschuren LJMJ, Kalivas PW (2000): Alterations in dopaminergic and glutamatergic transmission in the induction and expression of behavioral sensitization: A critical review of preclinical studies. Psychopharmacology 151:99-120

Vezina P (1996): D1 dopamine receptor activation is necessary for the induction of sensitization by amphetamine in the ventral tegmental area. J Neurosci 16:2411-2420

Vissavajjhala P, Janssen WGM, Hu Y, Gazzaley AH, Moran T, Hof PR, Morrison JH (1996): Synaptic distribution of the AMPA-GluR2 subunit and its colocalization with calcium-binding protein in rat cerebral cortex: an immunohistocemical study using a GluR2-specific monoclonal antibody. Exp Neurol 142:296-312

Wenthold R, Yokotani N, Doi K, Wada K (1992): Immunochemical characterization of the non-NMDA glutamate receptor using subunit-specific antibodies. Evidence for a hetero-oligomeric structure in rat brain. J Biol Chem 267:501-507

White FJ, Hu X-T, Zhang X-F, Wolf ME (1995): Repeated administration of cocaine or amphetamine alters neuronal responses to glutamate in the mesoaccumbens dopamine system. J Pharmacol Exp Ther 273:445-454

White FJ (1996): Synaptic regulation of mesocorticolimbic dopamine neurons. Annu Rev Neurosci 19:405-436

Wolf ME, Jeziorski M (1993): Coadministration of MK-801 with amphetamine, cocaine or morphine prevents rather than transiently masks the development of behavioral sensitization. Brain Res 613:291-294

Wolf ME (1998): The role of excitatory amino acids in behavioral sensitization to psychomotor stimulants. Prog Neurobiol 54:679-720

Yan Z, Hsieh-Wilson L, Feng J, Tomizawa K, Allen PB, Feinberg AA, Nairn AC, Greengard P (1999): Protein phosphatase 1 modulation of neostriatal AMPA channels: Regulation by DARPP-32 and spinophilin. Nature Neurosci 2:13-17

Zhang X-F, Hu X-T, White FJ, Wolf ME (1997): Increased responsiveness of ventral tegmental area dopamine neurons to glutamate after repeated administration of cocaine or amphetamine is transient and selectively involves AMPA receptors. J Pharmacol Exp Ther 281:699-706 